\title{
The use of digital games in the professional training of social pedagogues: realities and perspectives
}

\section{A utilização dos jogos digitais na formação profissional dos pedagogos sociais: realidades e perspectivas}

\section{El uso de los juegos digitales en la formación profesional de los pedagogos sociales: realidades y perspectivas}

\author{
Nadiia Chernukha1 ${ }^{\text {(iD }}$, Lyudmila Tokaruk ${ }^{1}$ iD, Alla Moskalenko $^{1}$ iD, \\ Maryna Vasylyeva-Khalatnykova ${ }^{1}$ iD , Alla Anatoliivna Zahorodnia ${ }^{2}$ iD, \\ Larysa Davydivna Kostenko ${ }^{3}$ iD
}

\footnotetext{
${ }^{1}$ Taras Shevchenko National University of Kyiv, Kyiv, Ukraine.

${ }^{2}$ National Academy of Pedagogical Sciences of Ukraine, Kyiv, Ukraine.

${ }^{3}$ Educational Department of Kropyvnytskyi, Kropyvnytskyi, Ukraine.
}

\section{Corresponding author:}

Nadiia Chernukha

Email: nm_chernukha@ukr.net

How to cite: Chernukha, N., Tokaruk, L., Moskalenko, A., Vasylyeva-Khalatnykova, M. O., Zahorodnia, A. A. \& Kostenko, L. D. (2022). The use of digital games in the professional training of social pedagogues: realities and perspectives. Revista Tempos e Espaços em Educação, 15(34), e17223. http://dx.doi.org/10.20952/revtee.v14i33.17223

\begin{abstract}
The article presents the possibilities of using digital games in the process of professional training of social educators. It was found that for the development of digital game-centered learning it is necessary to combine the efforts of public, private, charitable and public institutions and organizations that prepare for game design, training, organize exhibitions, competitions, festivals, which is the main direction of modern education as an important component. Competencies of the 21st century were talked about. It is determined that the use of computer games enhances the freedom of experiment, identity and social rewards, deepens personal experience by developing three basic needs for training motivation: competence (student feels the process of acquiring new knowledge and skills); autonomy (the student feels control over the educational process); interconnectedness (the student feels the connection with colleagues during the educational process). It is proved that the use of digital games in the professional training of social educators is an innovative and promising vector for the modernization of the educational process in modern higher education institutions as a whole.
\end{abstract}

Keywords: Digital technologies. Digital games. Professional training. Game-center training. 


\section{RESUMO}

O artigo apresenta as possibilidades de utilização de jogos digitais no processo de formação profissional de educadores sociais. Verificou-se que para o desenvolvimento da aprendizagem centrada no jogo digital é necessário combinar os esforços de instituições e organizações públicas, privadas, caritativas e públicas que se preparam para a concepção de jogos, formação, organização de exposições, concursos, festivais, que é a principal direcção da educação moderna como uma componente importante. Falou-se sobre as competências do século XXI. É determinado que a utilização de jogos de computador aumenta a liberdade de experiência, identidade e recompensas sociais, aprofunda a experiência pessoal ao desenvolver três necessidades básicas de motivação para a formação: competência (o estudante sente o processo de aquisição de novos conhecimentos e competências); autonomia (o estudante sente o controlo sobre o processo educativo); interconectividade (o estudante sente a ligação com os colegas durante o processo educativo). Está provado que a utilização de jogos digitais na formação profissional de educadores sociais é um vector inovador e promissor para a modernização do processo educativo em instituições de ensino superior modernas como um todo.

Palavras-chave: Tecnologias digitais. Jogos digitais. Formação profissional. Formação em centros de jogo.

\section{RESUMEN}

El artículo presenta las posibilidades de utilizar juegos digitales en el proceso de formación profesional de los educadores sociales. Se descubrió que para el desarrollo del aprendizaje digital centrado en los juegos es necesario combinar los esfuerzos de las instituciones y organizaciones públicas, privadas y benéficas que se preparan para el diseño de juegos, la formación, la organización de exposiciones, concursos, festivales, que es la dirección principal de la educación moderna como un componente importante. Se habló de las competencias del siglo XXI. Se determina que el uso de los juegos de ordenador aumenta la libertad de experimentación, la identidad y las recompensas sociales, profundiza en la experiencia personal desarrollando tres necesidades básicas para la motivación de la formación: competencia (el estudiante siente el proceso de adquisición de nuevos conocimientos y habilidades); autonomía (el estudiante siente el control sobre el proceso educativo); interconexión (el estudiante siente la conexión con sus compañeros durante el proceso educativo). Se ha demostrado que el uso de juegos digitales en la formación profesional de los educadores sociales es un vector innovador y prometedor para la modernización del proceso educativo en las instituciones de educación superior modernas en su conjunto.

Palabras clave: Tecnologías digitales. Juegos digitales. Formación profesional. Formación en centros de juego.

\section{INTRODUCTION}

In the modern educational space of higher education institutions, the use of digital games in the process of professional training is a topical issue today. In Ukraine, digital computer video games are the most common form today, so the categories "computer games", "digital games", "video games" are used as synonymous terms, used to describe games that take place on different types of computer monitors. There are types of digital games that combine portable electronic, console, video, audio and arcade games. The concept of "virtual game reality" stimulates the user to perform actions on the simulated system and shows the effects in real time.

It should be taken into account that computer games, their forms, types, features of influence on personality, possibilities of application in education have become the subject of 
research of cybernetics, economists, engineers, computer scientists, teachers, psychologists, physicians, sociologists, social educators.

An important place among certain areas of knowledge is currently occupied by social pedagogy, as its task is to substantiate the interaction of society and modern educational approaches, the conditions of use of games in various social forms of formal and non-formal education.

Note that most high-tech games are ineffective if players do not learn to play them, and teachers, social educators do not pay due attention to the development of methods for using games in the educational process. The influence of games on the development of players' cognitive, creative, communicative, collaborative skills contributes to the realization of a successful life in modern society (Oxford Analytica).

\section{ANALYSIS OF THE RESEARCH AND PUBLICATIONS}

The emergence and spread in the international educational space of the category "digital game-based learning", abbreviation: "DGBL") occurred after the release in 2001 of the first edition of Mark Prensky's book of the same name "Digital game-centered training" (Berg Marklund, 2015).

Game-based learning is an educational process in which play plays a central role, and the concept is used to describe the use of all types of games in the learning process (Berg Marklund, 2015).

It should be noted that Marc Prensky - American scientist, educator, writer, and publicist on innovation in education first introduced this category and noted: "In the last decades of the twentieth century there was a global technological boom that affected the cognitive processes of all actors' training" (Prensky, 2016, p. 56). He is the author of: "The world needs new curricula" (Prensky, 2014); "Education to improve their world: realizing the potential of children of the XXI century" (Prensky, 2016).

Bergom Marklund's scientific work states: "From the beginning of the XXI century begins the period of development of serious computer games, the purpose of which was not only to satisfy the desire of players to have fun, but also the realization of their educational needs" (Berg Marklund, 2015, p. 16).

The period we are studying covers the beginning of the XXI century and continues to this day. To determine the individual stages of development of game-centered learning, the following criteria were outlined:

- Intensification of scientific research of digital game-centered learning;

- Development, implementation of alternative educational models;

- integrating the efforts of formal and informal organizations to support digital gamecentered learning;

- Dynamic development of digital technologies and their implementation in educational practices;

- Acquisition of global game-centered learning of global characteristics.

On the basis of the defined criteria 3 historical stages of development of digital gamecentered training in the world are allocated: the first - 2001-2009 - a stage of preparation of educational innovations; the second - 2010-2015 - the stage of implementation of new educational models; the third - from 2016 to the present - the stage of globalization of game-centered learning (Tkachenko, 2015).

The first stage of development of digital game-center training 2001-2009 - the need for educational innovation corresponds to the year of the opening in New York of the first alternative school "Questto Learn", which was implemented on the basis of game-centered approach, which was embodied in the curriculum developed by experts from the Game Institut (World Government Summit, Oxford Analytica, 2016). 
According to M. Prensky (2006), 2001 was marked by the emergence of a new educational paradigm: "Digital game-centered learning is an alternative used with astonishing and growing success, and its mechanism works in educational organizations, secondary and higher schools and military institutions, from preschool to business training based on the use of games" (p. 94).

Thus, a new educational paradigm is formed - learning through play, and gradually emerges on the following grounds:

- Preschoolers learn the alphabet and learn to read using computer games;

- Elementary school students learn content with the help of Play Station, while the level of academic success increases by $30-42 \%$;

- Computer chess games become an essential part of the program of secondary education institutions;

- Computer games that use a set of texts occupy one of the first places among the sales of software;

- Sociologists play multiplayer online games to study the essence of political processes, including the electoral system;

- Financial workers use computer games to develop their competencies;

- Politicians play the game "SimCity-style" to understand the functioning of the health care system,

- Business leaders play on dynamic game simulators "HR" to learn how to operate refineries;

- Engineers use games to learn new technologies;

- Military personnel are trained by playing video games that simulate real battles (Prensky, 2006).

The discussion on the usefulness of using different types of computer games ends somewhat at the beginning of the XXI century, and its positive consequences paved the way for further use of games in the education of people of different ages in formal and non-formal education (Geta et al., 2018).

\section{METHODOLOGY}

The theoretical and methodological basis of the study is an interdisciplinary practiceoriented concept of studying the process of using digital games in the professional training of social teachers.

To solve the problems used general scientific methods:

1) Method of analysis and synthesis (in order to reveal the conceptual and categorical apparatus of research and scientific justification of the process of using digital games in the professional training of social teachers);

2) Scientific abstraction, induction and deduction (generalization of domestic and foreign experience in the study of this issue);

3) Abstract-logical (for theoretical generalization of research results and formulation of conclusions);

4) Special methods: mathematical and statistical processing of research results (for analysis of the survey);

5) Cross-tabulation and filtering results (for survey analysis);

5) Comparative data (for the analysis of the survey);

6) Data analysis (for survey analysis);

7) Systematization and differentiation (for the analysis of the survey);

8) Grouping, mean, standard deviation, regression, determination of the sample size, hypothesis testing (for survey analysis);

9) personalized Excel spreadsheets, graphical data expression (for survey analysis). 
The use of different methods presents the resulting data collected from a sample of respondents who participated in the survey. This data is comprehensive information collected from the target audience on a specific topic of interest for research based on this collected data. All methods allowed us to obtain objective information.

\section{RESULTS ANALYSIS}

Significant interest in the use of computer games in educational activities was studied by scientists: N. Avshenyuk, I. Bakhov (2021a; 2021b), V. Bykov (2010), N. Holavach (2020), O. Makarevich (2015), Y. Mielkov (2021), V. Zhukovsky, V. Kudin, N. Mukan (2011), A. Sbrueva (2004), L. Sergeeva (2014), J. Gee (2005a; 2005b; 2007; 2008), P. Gray, B. (2015; 2015, February 20).

Berg Marklund proved the long-term positive effects of video games on such mental processes as: perception, attention, imagination, memory, decision making. Currently, it is believed that computer games are created not only for entertainment, but also act as an important means of developing such skills as: coordination of movements and vision; spatial orientation; resource management; team work; communication; problem solving; reflective practices (Quest to Learn, n.d.).

The second stage of development of digital game-centered learning covered the years 20102015 and was the time of implementation of the latest educational models - educational innovations. During the second stage, two trends in the use of computer games begin to emerge: the first - a holistic educational curriculum for schools on the basis of game-centered learning and the second - the use of computer games in the study of individual school subjects (Berg Marklund, 2015).

The third stage of development of digital game-centered learning begins in 2016 and continues to this day. In 2016, a global government summit was held in the United States, which addressed the issue of "gamification" and the future of education (World Government Summit, Oxford Analytica, 2016). Based on the results of a study conducted by experts from Oxford Analytics (n.d.), where scientists expanded the content of the category "gamification" in the publication of reports: "Gamification and the future of education", where the concept of "gamification" was interpreted as the use of digital gaming elements.

It is no coincidence that the problems of "gamification" in education have been the subject of discussion at the world government summit, as the amount of time that modern pupils and students devote to computer games and communication on the Internet is growing (Tkachenko, 2015).

The use of computer games is an effective way to develop education, as games provide active experimental learning and gaming activities, encourage research on issues of global importance, interest in emotional activity, help develop critical thinking and problem-solving skills, stimulate the development of digital skills (Geta et al., 2018).

Based on the historical-retrospective analysis of the use of computer games and the study of the peculiarities of their use in the educational process, the leading trends in the implementation of digital game-centered learning were identified, namely:

- Introduction of computer games in the educational environment in the study of individual disciplines and in the implementation of integrated educational projects (social-humanitarian, natural-mathematical art);

- Implementation of alternative training focused on the dominant use of gaming activities, based on a specially designed curriculum (complete "gamification" of educational institutions);

- Use of computer games to teach people with special educational needs;

- Development of digital game-centered learning in the context of integration of formal and non-formal education and a combination of public and private sources of funding; 
- Use of computer games for the education of future citizens of the global world (Berg Marklund, 2015).

For the development of digital game-centered learning it is necessary to combine the efforts of public, private, charitable, public institutions and organizations that prepare for the study of game design, training, organize exhibitions, competitions, festivals, which is the main direction of modern education. .

The attention of the American public in the early 2000s was drawn to the urgent need to increase the level of knowledge in educational institutions about STEM disciplines: science (science), technology (technology), engineering (Mathematics), mathematics (Mathematics), combined in one block, based on the use of digital technologies and the Internet (Berg Marklund, 2015).

The application of methods of systematization and generalization allowed to state that the rapid development of digital technologies has significantly influenced the transformation of social and pedagogical approaches to training future social workers (Berg Marklund, 2015). Computer science helps young professionals to learn and express themselves through digital technologies. Having mastered the basic knowledge and skills, future social workers, social educators are able to create games, animations, websites and blogs, digital gadgets. Studying computer science is an effective way to get a quality education and create a foundation for a successful professional career (Berg Marklund, 2015).

Among the digital games used in the study of STEM-disciplines, a special place is occupied by epistemological games, which are based on simulation processes. The name "epistemological" comes from the Greek words "episteme" - knowledge, "logos" - teaching, because these games explore the process of acquiring knowledge, the structure of knowledge, their functioning and development. Simulation is a modeling of a natural phenomenon that allows dynamic and interact interactively with the subject of research. The use of simulations is appropriate and useful in the study of social sciences. Interactive characteristics of the simulation allow not only to observe the course of the phenomenon, but also to influence it, to experiment with (Levasseur, 2012; Ministry of Education and Science of Ukraine, 2017).

Among the scientists who have studied the impact of video game use on learning effectiveness, a special place is occupied by James Paul Gue (James Paul Gee) - an American scientist who conducted research in the field of pedagogy (the use of video games in education) (Prensky, 2016). In 2003, James Paul Guy conducted a study on "What Video Games Give to Teach Us to Literate" and singled out learning principles in the context of computer video games. These principles are formed as a result of early scientific work on the practical study of learning as a social activity. The scientist persuaded educators, parents, politicians, journalists and public figures, social workers to question conservative assumptions about the harmfulness of computer games and transform them into educational practices (Prensky, 2007).

\section{RESULTS AND DISCUSSIONS}

Quite productive and interesting for modern educational practice is defined by James Paul Guy 16 stages of specialists to study STEM disciplines: (Ministry of Education and Science of Ukraine, 2017; Prensky, 2016).

1. Identity. Players form a new identity through playing video games. The scientist emphasizes that there can be no question of deep assimilation of knowledge as long as students do not show a pronounced motivation for long-term learning.

2. Interaction: communication takes place between the player and the game. The scientist quotes Plato's words about the passivity of books in the sense that readers cannot force books to talk to them in a way that occurs when one person has a real dialogue with another during a faceto-face meeting. . Games interact, speak in a peculiar way, with the player, nothing happens in the 
game until the player makes a decision and begins to act, then the game begins to respond, responding to the actions of the player, sets him new tasks.

3. Creativity. Players help to make up a story through some form of interaction, such as solving a puzzle or completing a level (computer game). Players are producers, not just consumers, writers, not just readers, so in simple games, players become co-creators of games, by performing actions and making decisions, at the simplest levels, players jointly develop games through their actions and the decisions they make to accept them.

4. Risk taking. Losing in the game leads to insignificant consequences compared to real life, which motivates players to take risks. Good video games reduce the negative effects of a loss and create the conditions for accepting a loss, and players can start playing again from the last saved stage of the game before they fail. Players are encouraged to take risks, explore and try to act in new ways. In the game, loss is a motivating element, where players use initial failures as ways to find new solutions and get feedback on the progress made. University education provides students with far fewer opportunities for risk, research, and trial and error (Quest to Learn, n.d.).

5. Settings. Games usually offer a customization level so that users can play- and succeed at the level of their gaming competence. Players can usually, in one way or another, adapt the game to their own learning and game styles. Games often have different levels of difficulty and many good games allow players to solve problems in different ways. In role-playing games, each player chooses distinctive features for his character and determines how the game will take place. Players can even try new game styles. Individually tuned university programs should not only correspond to the speed of knowledge acquisition by individual students, but also be adapted to their interests, desires, learning styles.

6. Management. Players control the game sphere, thanks to the listed principles, they feel real control over the game and over what they do, such a feeling of power over educational activities is practically impossible in the student environment (Quest to Learn, n.d.).

7. Well-organized tasks. Orderly problems - the game environment contains tasks that follow each other, allowing the player's skills to grow and develop. In smart video games, the tasks given to players are arranged in such a way as to lead players to form hypotheses that will help them solve complex problems. Due to the good organization of the problem space of the game, there are different levels of complexity of game actions (Quest to Learn, n.d.).

8. Challenge and consolidation. Smart games offer players a set of challenging tasks and then allow them to solve those tasks until they become routine for the players and are automatically solved by them. Then the game puts forward a new class of tasks for the players, which requires them to rethink the ways of acquiring skills, learning something new and integrating this new into the system of previously acquired skills. This cycle is called the "examination cycle" and is the path that a player must take to become an expert in gaming.

9. Timely and on demand. Players receive the necessary information just when they need it, not before, which teaches them patience, perseverance and improves the ability to think critically. Games almost always provide verbal support, either "just in time", i.e. when they need it and can use it, or "on demand", when players feel the need, want to receive information, are ready to receive it and use it productively. The submission of educational material should take place in a similar way at the university (Quest to Learn, n.d.).

10. Situational understanding. Games always give the meaning of words in the names of actions, images and dialogues that relate directly to them and show the meaning of words by varying different actions, images and dialogues, they do not offer words for words, but offer them to perform game actions.

11. Pleasant obstacles. Game tasks must be challenging enough for players to throw at them challenges, but be easy enough for players to believe in the possibility of overcoming them. Due to most of the above principles, good games are always close in terms of difficulty, but at the next level 
of competence of the player, that is, they are perceived as a difficult but accessible task that puts the player in a position of high motivation.

12. System thinking. Games encourage players to think about relationships, rather than isolated events, facts, and skills. In a game like Rise of Nations, players need to think about how each action they take can affect their future actions and the actions of other players playing against them, as each of them leads their civilizations through the ages. In a massively multiplayer game like World of War Craft, players must think about the consequences of their actions not only for all aspects of the game world, but also for many other players. In our complex global world, the ability to think systematically is important for everyone.

13. Research, lateral thinking, rethinking goals. Games force players to expand situational knowledge and take into account the various possible consequences of actions, encourage players to carefully study the situation before moving too fast to think laterally (creatively and indirectly), not just linearly, use research results and lateral thinking to rethink their goals from time to time.

14. Reasonable means and distributed knowledge. Using game tools, players gain the ability to share their knowledge with others. The virtual character, or characters that are manipulated in the game and many other components in the game world, are actually "smart tools". Virtual characters have their own skills and knowledge, which they pass on to players. In massively multiplayer games, players work in teams, where each participant contributes their unique skills, and the basic knowledge needed to play today is shared between real people's teams and their clever virtual characters. Smart tools and distributed knowledge are keys to modern jobs, but this approach is not always implemented in modern schools.

15. Cross-functional commands. Players play in cross-functional teams and must use everyone's knowledge and skills in combinations and collaborations to progress in the game. When players play a massively multiplayer game, such as World of war craft, they often work in teams (guilds), in which each player has a set of skills, and in such groups, players are bound by their desire to jointly perform a game task, rather than primarily, their racial, class, ethnic or sexual affiliation. These characteristics can be available as resources for the whole group, if they are needed, and when the player wants to use them, so such cross-functional teams are organized for modern activities, although this approach is not always implemented in educational institutions.

16. Acquisition of competence in the course of game tasks. Competence is formed by performing actions. Intelligent video games operate on the principle that is the opposite of what is implemented in educational institutions - performance before competence. Players can perform an action before they are competent, supported by game design, clever means of play, and often the support of other, more experienced players (multiplayer games in chat rooms or physical space) (Quest to Learn, n.d.).

As a leading expert in game-centered learning, defining the learning principles, opportunities that give games, J. Guy in 2003 asked the question: "How to organize learning? With or without games for implementing in modern learning principles"? The answer was unequivocal; you need to learn to use games in the educational process (Prensky, 2007). Note that the "Guidelines for the implementation of STEM - education in educational institutions of Ukraine for the 2017-2018 school year", posted on the website of the Ministry of Education and Science of Ukraine, due attention to foreign experience in the use of computer games in the educational process (Computer Science Teachers Association [CSTA], 2017; Eichenbaum et al., 2014).

It is undeniable that STEM - education is aimed at activating teachers and students to use games in the educational process, and this stage is characterized by cooperation of public, private, public organizations to support the development of digital game-centered learning, assistance in implementing innovative educational models (Ministry of Education and Science of Ukraine, 2017). 
Prospects for the development of digital game-centered learning were identified by the American scientist M. Prensky (2007). The scientist's prediction about computer games is formulated in the following provisions:

- Games will become more realistic, exploratory and such that give players a feeling of complete immersion in the game reality;

- Games will take place online and can be played by a large number of users;

- Games will combine the best narratives, characters and realize the interaction between them;

- Most games will be dedicated problems of human interaction;

- Communication and cooperation will become more important elements of the game;

- Players will be able to create their own games according to the desired scenario;

- There will be new game forms and games with new themes;

- Entertaining games will be publicly available;

- Games will be of the highest quality;

- Games will become more exciting and interesting.

Generalized research results and prospects for the use of computer games scientists James P. Gee (2005a; 2005b; 2007; 2008), Richard Halverson (Richard Halverson), David W. Schaffer (2005), Shapiro J. $(2014 ; 2018)$ formulated in such provisions:

- video games are virtual learning worlds characterized by strong educational potential, because by playing games, students form effective social skills, have the opportunity to explore new identities;

- video games are important because they allow students to learn new worlds, think, speak and act - to live, performing roles that are not available to them in traditional reality;

- Creating virtual worlds, games integrate knowledge and actions;

- Games combine situational understanding, effective social practices, strong identities and shared values that enable players to play the role of experts;

- Playing games, students learn, constantly receiving new information;

- Video games are important because they allow people to participate in new worlds, allow players to think, speak and act - to live in virtual reality, performing roles that are not available to them outside the game space;

- The task for game designers and universities is to understand how to shape the educational process;

- Video games can change the methodology of education;

- The use of video games allows the education system to move beyond traditional disciplines.

The use of computer games enhances the freedom of experimentation, identity and social realities, deepens personal experience by developing three basic needs for motivation:

- Competence (the student feels the process of mastering new knowledge and skills);

- Autonomy (the student feels control over the educational process);

- Interconnectedness (the student feels a connection with colleagues during the educational process).

Given the above, we can say that gamification is becoming part of the future of education. However, only after conducting pilot research programs that will show where it is most useful to apply (McCall, 2011).

We describe the technological prerequisites:

- Technology dominates most of the discourse of gamification, but gamification does not always involve the use of computer games;

- One of the most important technological prerequisites for gamification is a fully internalized educational system (Hangen, 2015). 
Educational prerequisites:

- Teachers must be able to select the most appropriate elements of gamification to teach the subjects they teach, as well as have the ability to consistently and gradually implement gamification;

- Crucial to teachers are the ability to respond to the individual needs of students when they arise, to assess the impact of gamification in real time and on an ongoing basis;

- For the successful dissemination of gamification, it is advisable to conduct broad outreach work among the public;

- Professional and thorough preparation of gamified educational content should be in the field of constant attention of game designers, scientists, educators, all those who may be involved in the manufacture and use of computer games.

The key figure in the implementation of digital game-centered learning is teacher; therefore, it is advisable to develop recommendations for teachers of higher education. To implement this task, research work was conducted, which consisted of four stages:

- The recommendations of foreign scientists who offer to use digital games for educational purposes are analyzed;

- Studied the difficulties of implementing an innovative approach that teachers face, and clarified ways to overcome them;

- The preconditions for the use of digital games in the educational process are studied;

- Based on the results of the study, recommendations for the use of computer games in the educational process are formulated.

We describe the results obtained during the implementation of each stage.

A prerequisite for the successful use of digital games in the educational process is the awareness of teachers of the following provisions:

- Computer games activate, not displace from the educational process, the interaction between teacher and students, do not transform his work;

- Digital games are tools that teachers can use to improve learning;

- Computer games provide a variety of approaches to the development of meta-cognitive skills through constant self-reflection and practice of a certain group of skills;

- Digital games can create a research-experimental contextualization of learning through the use of virtual simulations;

- Computer games are a good way to create an exciting interdisciplinary space in.

Understanding of these provisions comes as a result of participation in trainings, seminars, specially organized for teachers, which also contributes to the formation of teachers' motivation to use computer games. Teachers master practical skills to use computer games in teaching. We describe the practical steps that a teacher must perform to implement digital game-centered learning.

Step 1. Evaluate available resources.

Teachers should analyze the state of provision of technological equipment necessary for the use of computer games. The following computer resources are used for this purpose: tablets, laptops, etc. The key point in the process of evaluating technological equipment is to find out how much it can provide the implementation of educational tasks.

Step 2. Finding games.

Once the teacher has decided what equipment is at his disposal, you can start looking for games. This can be done through sites that offer games. It is also important to get acquainted with the experience of colleagues who use games, reading their blogs or through electronic social networks.

Step 3. Play games. 
Once the teacher has chosen a game, he needs to play that game from start to finish. Games are not similar to textbooks or handouts, and the process of preparing a teacher to use games is not similar to working with a textbook, i.e. it will not be enough to just read the content. It is also insufficient to get acquainted with the mechanisms of the game.

Before students begin to play, the teacher must acquaint them with the categories, concepts used in the game. When students have completed the game, teachers can discuss how to present the main conceptual idea in the game. The successful experience of teachers confirms that games can be an important tool for project-based learning.

Step 4. Search for supporting materials.

Digital game-centered learning is quite popular, however, finding supporting materials is not easy enough, as most sites offer only a brief description of the games. Teachers should pay attention to the sites of digital game developers, which post video lessons and other materials for teachers.

Step 5. Study the experience of others.

Increasing the level of pedagogical skills in the use of computer games in the educational process contributes to the observation of the process of implementation of game-centered learning by modern teachers. There are special series @Learning through games@on the Internet, looking at which you can explore how new teachers use games in the learning process.

On the basis of the Taras Shevchenko National University of Kyiv, a survey was conducted among 25 teachers and 45 students of the Social Pedagogy OPP. According to the results of the survey, it became clear that respondents are ready to use different types of digital games in educational and professional activities. It is believed that digital games develop cognitive abilities and are an effective and convenient professional tool. More than $90 \%$ of respondents believe that digital games affect the personality of the future specialist. They have the following positive forms of influence: they develop cognitive, creative, communicative and collaborative skills (Among the negative - gambling addiction).

Respondents were introduced to possible areas of application of digital games in scientific fields (figure 1):

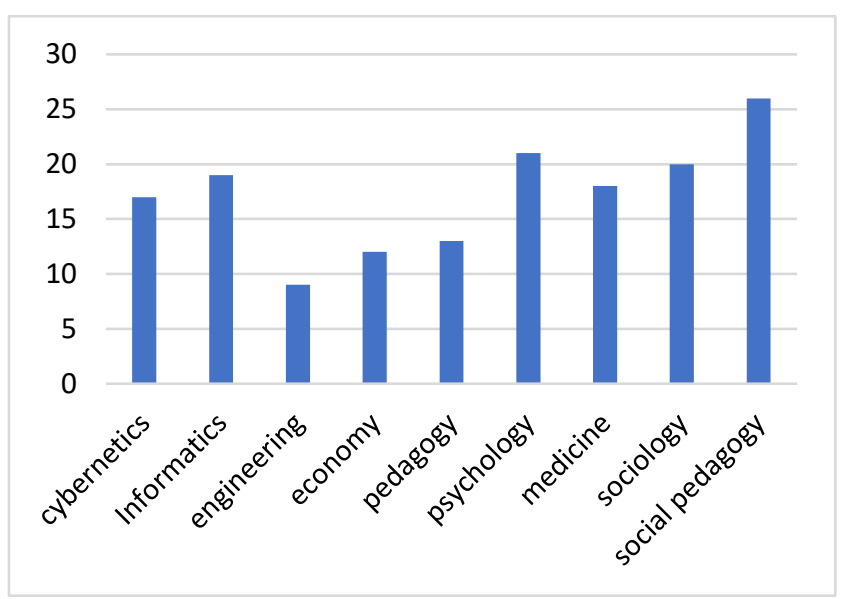

Source: developed by the authors

Figure 1. Possible areas of application of digital games in scientific fields

Most respondents believe that the digital game is a game played on a computer using special programs that provide interaction between players in cyberspace based on certain rules, $25 \%$ of respondents believe that in formal educational practices are most widely used digital games, and $75 \%$ - informal (figure 2). 


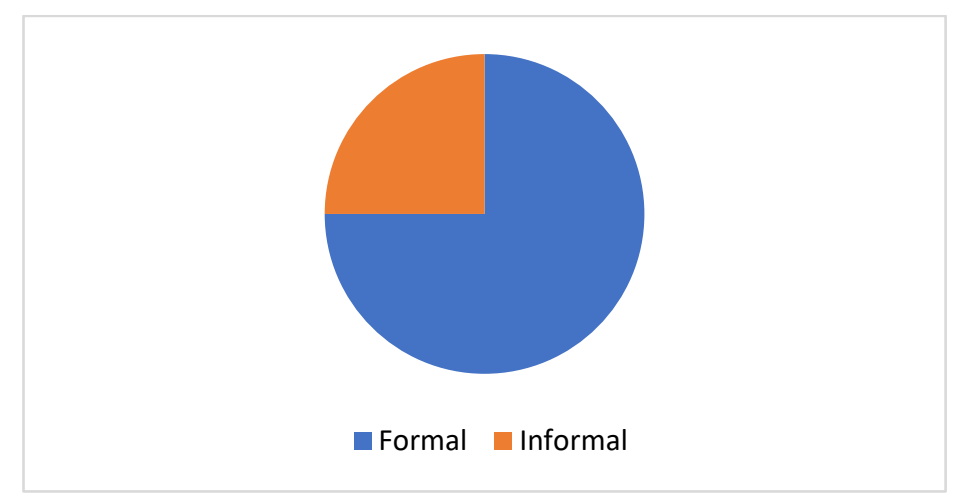

Source: developed by the authors

Figure 2. Attitude of respondents to digital games

More than $90 \%$ of respondents believe that the key strategies for digital learning are:

- stimulating the development of the need to learn;

- iteration (repetition, study of the same problem from different points of view);

- creation of special educational environments: "small laboratory" (mixed reality environment that uses video cameras and digital projections to create learning scenarios);

- interaction with game designers.

Based on a study conducted at the Faculty of Psychology of Taras Shevchenko National University of Kyiv, which was attended by 25 teachers and 45 students of OPP "Social Pedagogy", 8 main difficulties encountered by teachers and students during game-centered learning, suggested ways to overcome them, among them:

1) Lack of time. $35 \%$ of teachers reported that there was not enough time to implement digital game strategies; they believed that first you need to present the teaching material in the traditional way, and only then use games to consolidate what has been learned. To overcome this obstacle, it is necessary to understand that games can be implemented in the daily educational process, as the formation of basic concepts provided by the curriculum takes place in a game context, research and experimental way. Games provide an opportunity to deepen knowledge and gain new ones in the course of gaming activities;

2) High cost of games. $40 \%$ of students reported that the price of games often exceeds the available financial resources, so students do not want to spend their own money to buy games. At the initial stage of game-centered learning, you should use freely available games;

3) Insufficient technological resources. $25 \%$ of teachers reported that the lack of technological resources hinders them from implementing digital gaming strategies. As a rule, a sufficient number of technological resources are associated with the concept that every student should have a tablet or laptop during the game training. To overcome this obstacle, it is necessary to implement group game-centered learning, during which students learn to cooperate and interact with each other. You can also divide the audience into several groups: one group of students plays the game, while others are engaged in non-digital activities. It is necessary to rotate groups;

4) Difficulties in finding games that match the curriculum. $30 \%$ of teachers said that it is difficult for them to find games that correspond to the theme of daily activities to overcome this obstacle and recommend visiting the sites where the games are presented according to the possibilities of their use in the study of various disciplines. At the same time, it is important to remember that the game is an additional tool that expands the possibilities of traditional learning. It is not necessary that the topic of the game is directly related to the topic of the lesson, because games can present educational material from other perspectives, while broadening the horizons of students and deepening their skills;

5) Preparation for test assessment is the dominant curriculum. $25 \%$ of students reported that the emphasis on preparation for standardized tests makes the use of digital games problematic Note 
that the developers of modern digital educational games define a set of standardized skills that students must master during play activities ;

6) Lack of information on where to find quality digital games. $17 \%$ of students said they did not know where to find quality digital games. To overcome this obstacle it is necessary to get acquainted with a special technique of digital games for educational activities;

7) Lack of knowledge of teachers on the integration of games into the educational process. $10 \%$ of teachers said they did not know how to implement digital games in the educational process. To overcome this obstacle, teachers are encouraged to take advantage of the following opportunities: training in special courses; consult an experienced colleague; to get acquainted with articles, manuals, which cover the use of digital games in the study of humanities;

8) Insufficient level of digital competence of teachers. $18 \%$ of students reported that teachers did not have enough digital skills. There are two ways to overcome this obstacle: to increase the level of digital competence or to use non-digital games in the educational process.

\section{CONCLUSIONS}

That is, in the Ukrainian educational realities the problem of students' lack of desire to study is becoming more and more noticeable. The main reason for this situation is a fairly common rational-pragmatic approach to learning. Of course, the implementation of digital game-centered learning is not a panacea, but its high pedagogical potential and the success of international schools in its implementation, justify the assumption that the use of computer games will be effective and give the educational process attractive characteristics. , make mistakes in order to succeed, feel the happiness of self-realization.

Prospects for the development of the use of digital game-centered learning in the educational space are determined on the basis of the results of the study of gamification and the future of education.

The developed recommendations for teachers, combining the following practical steps, are analyzed:

1) Evaluation of available resources;

2) Finding games;

3) Game in game;

4) Search for auxiliary materials;

5) Studying the experience of others, etc.

Based on the analysis of the source base and own research results, recommendations for the use of computer games at three educational and social levels: educational and public, educational and institutional, educational and personal.

Today, it has been proven that games have a rich educational potential, however, it is time to focus on training specialists in the field of game design, gamification of socio-pedagogical education, experimental implementation and dissemination of research results among the general pedagogical community. In order for digital game-centered learning to be effective in Ukrainian realities, pilot programs and carefully conducted research, support for patrons, charitable foundations, and the promotion of open information exchange between universities and educational schools are needed to help advance the development of educational tools for student training.

Authors' Contributions: Chernukha, N.: conception and design, acquisition of data, analysis and interpretation of data, drafting the article, critical review of important intellectual content. Tokaruk, L.: conception and design, acquisition of data, analysis and interpretation of data, drafting the article, critical review of important intellectual content. Moskalenko, A.: conception and design, acquisition of data, analysis and interpretation of data, drafting the article, critical review of important intellectual content. Vasylyeva-Khalatnykova, M. O.: conception and design, acquisition of data, analysis and interpretation of data, drafting the article, critical review of important intellectual content. 
Zahorodnia, A. A.: conception and design, acquisition of data, analysis and interpretation of data, drafting the article, critical review of important intellectual content. Kostenko, L. D.: conception and design, acquisition of data, analysis and interpretation of data, drafting the article, critical review of important intellectual content. All authors have read and approved the final version of the manuscript".

Ethics Approval: Not applicable.

Acknowledgments: Not applicable.

\section{REFERENCES}

Bakhov, I., Byrkovych, T., Makarchuk, O., Varyvonchyk, A., \& Turchak, L. (2021a). Enhancing cross-cultural competence of students under conditions of limited social communication. AdAlta: Journal of Interdisciplinary Research, 11(1 S18), 51-57.

Bakhov, I, Opolska, N., Bogus, M., Anishchenko, V., \& Biryukova, Y. (2021b). Emergency distance education in the conditions of COVID-19 pandemic: Experience of Ukrainian universities. Education Sciences, 11(7), 364.

http://dx.doi.org/10.3390/educsci11070364

Berg Marklund, B. (2015). Unpacking digital game-based learning: The complexities of developing and using educational games. Doctoral Dissertation. University of Skövde, Skövde, 302 p.

Bykov, V., Belous, O., \& Bogachkov, Yu. (2010). Fundamentals of standardization of information and communication competencies in the education system of Ukraine: Methodological recommendations. Kyiv: Attica, $88 \mathrm{p}$.

Computer Science Teachers Association [CSTA]. (2017). K-12 Computer Science Standards, Revised 2017. Available: https://www.doe.k12.de.us/cms/lib/DE01922744/Centricity/Domain/176/CSTA\%20Computer\%20Science\%20Standar ds\%20Revised\%202017.pdf

Eichenbaum, A., Bavelier, D., \& Green, S. (2014). Video games: Play that can do serious good. American Journal of Play, 7, 50-72.

Gee, J. P. (2005a). Good video games and good learning. Phi Kappa Phi Forum, 85(2), 33-37.

Gee, J. P. (2005b). Learning by design: Good video games as learning machines. E-Learning and Digital Media, 2(1), 516.

Gee, J. P. (2007). What video games have to teach us about learning and literacy. New York: Palgrave Macmillan, 256 p.

Gee, J. P. (2008). Learning and games. In: Salen, K. (Ed.). The ecology of games: Connecting youth, games, and learning. The John D. and Catherine T. Mac Arthur Foundation series on digital media and learning. Cambridge: The MIT Press, pp. 21-40.

Geta, A. V., Zaika, V. M., Kovalenko, V. V., Kosova, K. O., Leshchenko, M. P., Leshchenko, P. A., Matyukh, Zh. V., Netiosov, S. I., Nosenko, Yu. G., Somenko, D. V., Somenko, O. O., Tarasyuk, M. D., Timchuk, L. I., Chernov, A. A., Shishkina, M. P., \& Yatsishin, A. V. (2018). Modern means of ICT support inclusive education: A textbook. Poltava: PUET, $261 \mathrm{p}$.

Gray, P. (2015). Free to learn: Why unleashing the instinct to play will make our children happier, more self-reliant, and better students for life. $1^{\text {st }}$ ed. Basic Books, $288 \mathrm{p}$.

Gray, P. (2015, February 20). Cognitive benefits of playing video games: Research shows that video-game play improves basic mental abilities. Available: https://cdn.psychologytoday.com/blog/freedom-learn/201502/cognitive$\underline{\text { benefits-playing-video-games }}$

Hangen, T. (2015). Historical digital literacy, one classroom at a time. Journal of American History, 101(4), 1192-1203.

Holovach, N. V., Dmitrenko G. A., \& Bakhov, I. S. (2020). Digitalization of the education system: Formation of personality according to parameters. Journal of Advanced Research in Dynamical and Control Systems, 12(SI 04), 849860.

Levasseur, A. (2012, February 6). Epistemic games are the future of learning, letting students role-play professions. Available: http://mediashift.org/2012/02/epistemic-games-are-the-future-of-learning-letting-students-role-playprofessions037/

Makarevich, O. O (2015). Gamification as an integral factor in improving the effectiveness of elements of distance learning. Young scientist, 2(17), 275-278. Available: http://molodyvcheny.in.ua/files/journal/2015/2/357.pdf 
McCall, J. (2011). Gaming the past: Using video games to teach secondary history. New York; London: Routledge, 216 p.

Mielkov, Y., Bakhov, I., Bilyakovska, O., Kostenko, L., \& Nych, T. (2021). Higher education strategies for the 21st century: philosophical foundations and the humanist approach. Revista Tempos E Espaços Em Educação, 14(33), e15524. https://doi.org/10.20952/revtee.v14i33.15524

Ministry of Education and Science of Ukraine. State Scientific Institution "Institute for Modernization of Educational Content". (2017). Methodical recommendations on the implementation of STEM-education in secondary and out-ofschool educational institutions of Ukraine for the 2017/2018 academic year No. 21.1/10-1470 dated July 13, 2017. Available: http://yakistosviti.com.ua/userfiles/file/web-stem-shkola/22-serpnia/Vasilashko-Irina-Pavlivna/1-metodrekomend-2017.pdf

Mukan, N. V. (2011). Professional development of teachers of secondary schools in Great Britain, Canada, USA: A monograph. Lviv: Lviv Polytechnic, 248 p.

Oxford Analytics. (n.d.). Available: https://www.oxan.com/

Prensky, M. (2006). Don't bother me mom - I'm learning! Saint Paul: Paragon House Publishers, 350 p.

Prensky, M. (2007). Digital game-based learning. $3^{\text {rd }}$ ed. Saint Paul: Paragon House Publishers, 464 p.

Prensky, M. (2014). The world needs a new curriculum. The Global Future Education Foundation and Institute, 72 p.

Prensky, M. (2016). Education to better their world: Unleashing the power of 21st century kids. New York: Teachers College Press, $144 \mathrm{p}$.

Quest to Learn (Q2L). (n.d.). Middle School and High School. Available: https://www.q2l.org/

Sbrueva, A. A. (2004). Trends in reforming secondary education in developed English-speaking countries in the context of globalization (90s of the XX - early XXI century): Monograph. Sumy: Kazachiy val, $500 \mathrm{p}$.

Sergeeva, L. (2014). Gamification: game mechanics to motivate staff. Theory and methods of education management, 2(14). Available: https://lib.iitta.gov.ua/6072/

Shaffer, D. W., Squire, K. R., Halverson, R., \& Gee, J. P. (2005). Video games and the future of learning. WCER Working Paper No. 2005-4, 13 p. Available: https://wcer.wisc.edu/docs/working-papers/Working_Paper_No_2005_4.pdf

Shapiro, J. (2018). Digital play for global citizens. New York: The Joan Ganz Cooney Center at Sesame Workshop, 37 p.

Shapiro, J., Salen Tekinbaş, K., Schwartz, K., \& Darvasi, P. (2014). The mind shift guide to games and learning. New York: The Joan Ganz Cooney Center, $41 \mathrm{p}$.

Tkachenko, O. (2015). Gamification of education: formal and informal space. Current issues of the humanities, 11, 303309.

World Government Summit, Oxford Analytica. (2016). Gamification and the future of education. p. 19. Available: https://www.worldgovernmentsummit.org/api/publications/document?id=2b0d6ac4-e97c-6578-b2f8-ff0000a7ddb6

Received: 9 August 2021 | Accepted: 12 November 2021 | Published: 31 January 2022 